\title{
Ownership Structure and Business Firm Value: A Study of Non-financial Sector of Pakistan
}

\author{
Muhammad Usman * $\quad$ Hassan Mobeen Alam ${ }^{\dagger}$
}

\begin{abstract}
The basic purpose of this study is to examine the association of ownership structure $(O S)$ with value of business firms (VBF). By using panel date techniques, the relationship between $O S$ and VBF has been statistically tested. OS is used as an explanatory variable, whereas, for measuring VBF, accounting base performance measures (short term performance) includes return on assets (ROA) and return on equity (ROE) and market base performance (long term performance) has been measured through Tobin's $Q$. The study also emphasizes the firm age as an interactive variable. Ownership role is examined from the perspective of agency theory (AT) and by using resource dependence theory (RDT). The sample consists of 135 companies and having 1890 observations of non-financial sector listed on Pakistan Stock Exchange (PSX) for the time period 2004 to 2017. Researchers has applied descriptive and inferential statistics techniques to analyze the gathered data. Findings reveal that some dimensions of $O S$ significantly influence the short term and long run firm performance (FP) under interactive role of age. The study aims at contributing useful knowledge generally for the financial community, and specifically for investors, researchers, and regulators.
\end{abstract}

Keywords: Corporate Governance, Ownership Structure, Value of Business Firms, Firm Age, Non-Financial Sector, Agency Theory, Resource Dependence Theory.

\section{Introduction}

Good CG practices are needed for a country's economic growth and viability, because such practices provides credibility and confidence to the economic participants that are fundamental to capital markets development (Detthamrong, Chancharat, \& Vithessonthi, 2017). An effective CG system is also considered to be an essential driver for corporate performance, and to improve the confidence and trust of equity financiers (Pillai \& AlMalkawi, 2018). Whereas, poor CG practices lead towards lack of transparency and insider trading which are critical for market integrity and fair trading of stocks (Claessens \& Yurtoglu, 2013).

CG system includes both internal and external mechanisms (Chhillar \& Lellapalli, 2015). Internal and external CG control mechanisms are part and parcel to each other. The most important internal CG tool includes the board structure and equity OS, whereas, the basic external CG control elements include the market for corporate takeover and the

${ }^{*}$ PhD Scholar and Assistant Professor, Hailey College of Commerce. E-mail: usmanhc@yahoo.com

${ }^{\dagger}$ Professor, Hailey College of Commerce. E-mail: hassanmobeen@yahoo.co.uk 
legal setup in which the BF operate. The significance of internal $\mathrm{CG}$ is much wider than external CG (Denis \& McConnell, 2003).

OS is an important factor in internal CG mechanism because it affects the corporate decision making, managerial behavior, stockholder voting in electing board and company's performance (Kumar \& Zattoni, 2014a). This factor is closely related with agency problem (AP). Pattern of OS is considered important to know and judge about the dilemma of $\mathrm{AP}$ in an organization. When equity ownership is widely dispersed, the business firms (BF) face type-I AP, which is the disagreement of minority shareholders on the policies of firms managers (Kumar \& Zattoni, 2014a). Conversely, in highly concentrated OS, the companies face type-II agency problem which include clashes of interests among dominating and minority shareholders (Kumar \& Zattoni, 2014b). It is also worth sharing that the ownership of large block holdings is a key CG mechanism to resolve type-1 AP, because they may be fine monitors of upper level management (Boyd, Gove, \& Solarino, 2017). Regardless of increasing interests of research community on the said area, many essential dimensions of OS, and with interactive role of different variables and its effects on firm performance (FP) remain unknown. (Kumar \& Zattoni, 2018).

The relationship between OS and VBF has widely been studied in developed economies of the world. It can also be an important source of incentive for the researchers to investigate OS with respect to developing economy like Pakistan with a number of ownership patterns such as ownership concentration (OC), institutional ownership (IO), family and founder ownership (FAMO), government ownership (GO), foreign ownership (FO), management ownership (MO), directors' ownership (DO), corporate ownership (CO), retail ownership (RO) and business group affiliation (BGA) with VBF. The main dependent variables include ROA, ROE and Tobin's Q. A review of literature related to Pakistan shows no empirical evidence related to various aspects of ownership structure namely; GO, CO, RO BGA and their inter-relationship with FP. Additionally, interactive role of age has not been investigated thoroughly in aforesaid relationship. This paper aims at bridging the identified gap by investigating the above mentioned dimensions of OS in FP of non-financial sector firms with comprehensive data set.

This study focuses on non-financial sector of Pakistan. Non-financial sector primarily include manufacturing industries. This sector is a backbone to the economy and plays a significant role through economic development and value addition. According to Pakistan Economic Survey 2017-18, the overall contribution of this sector to GDP is 13.6\%, and according to the Financial Statement Analysis of Non-Financial sector (State Bank of Pakistan) this sector reported $19.23 \%$ growth in sales during the fiscal year 2018 as compared to the previous fiscal year 2017. Furthermore, in line with the previous studies, financial sector is excluded from the sample due to the difference of financial reporting and regulatory framework (Ciftci, Tatoglu, Wood, Demirbag, \& Zaim, 2019).

Research on CG is supported by different theories. Marie L'Huillier (2014) stated that the main theories of CG are: agency theory (AT), resource dependency theory (RDT), stakeholder theory (ST) and stewardship theory (ST). This study focuses on only two theories: AT and RDT. OS is focused to know the nature of AP in a BF because it affect FP. Similarly, the study also finds the resource dependence role of the ownership towards enhancing VBF. 
The study is aimed at achieving the following objectives.

1. To measure the OS and VBF relationship in Pakistan.

2. To test the moderating role of firm age in association with OS and $\mathrm{VBF}^{1}$.

The study results provides that OC positively influence the accounting base performance as well as market base performance of BF. The results of this variable are consistent with Javid and Iqbal (2010). This also supports AT in resolving type-I agency problem. FO positively influence the long run performance of $\mathrm{BF}$ and these are correlated with (Mukhopadhyay \& Chakraborty, 2017). BGA has inverse effect on ROA, ROE and Tobin's Q which is in line with the results of Bertrand, Johnson, Samphantharak, and Schoar (2008). The results also reveal that CO has no influence on ROA, ROE and Tobin's Q, which are consistent with Ciftci et al. (2019). FAMO has also negative impact on market base performance. Whereas, MO has negatively affect the short run FP. Leverage and asset tangibility have negatively influence the VBF. However, firm size has direct relationship with both accounting base and market base FP. Interestingly under interactive condition of age, both $\mathrm{MO}$ and BGA have positive effect on VBF. GO has only direct effect on short run performance. Similarly, RO has also positive influence on ROA under interactive role of age. Furthermore, IO has negative effect on VBF when age is used as an interactive variable. $\mathrm{CO}$ has also inverse relationship with ROA and ROE in this position.

\section{Literature Review}

OS is regarded to be an important factor in corporate governance research. Equity ownership stake influence the managerial behavior, FP and stockholder voting in electing board. Past studies regarding different dimensions of OS and VBF are reviewed in the following section.

Ownership concentration (OC) prevails in various developing and emerging economies (Cueto \& Switzer, 2015). Controlling shareholders (ownership concentration) monitor the activities of managers for exercising their control rights. Due to their access to information and presumed part in decision making of an organization, AP type I can be minimized. Javid and Iqbal (2010) reported a positive association between OC and FP. Similar findings were found by Hanafi, Setiyono, and Sanjaya (2018). However, Kirchmaier and Grant (2005) observed that OC in European countries is not correlated and consistent with philosophy of value maximization by stating that the dominant shareholders damage the organization value. The study of Wang (2018) reported a u-shaped relationship between $\mathrm{OC}$ and VBF. From AT perspective, the above results induced that OC tends to reduce type I AP.

$H_{1}$ : A significant association exists between $O C$ and $F P$.

\footnotetext{
${ }^{1}$ In this research paper, the words value and performance are used interchangeably.
} 
Individual/ retail ownership ( $\mathrm{RO})$ is also used and investigated as an ownership variable and its relationship with various FP measures. Henry (2010) found that RO insignificantly and negatively influence on Tobin's Q. Furthermore, Jameson, Prevost, and Puthenpurackal (2014) reported a significant inverse linkage of Tobin's Q with RO for Indian firms.

$\mathrm{H}_{2}$ : There is a significant relationship exists between $\mathrm{RO}$ and FP.

In the context of emerging market, it has been evidenced that with greater foreign ownership (FO), FP increases more than in local firms (Yudaeva, Kozlov, Melentieva, \& Ponomareva, 2003). Javid and Iqbal (2010) documented a statistically direct association of foreign ownership with accounting and market base value measures. Furthermore, Mukhopadhyay and Chakraborty (2017) evidenced that institutional FO has much strong impact on ROA and Tobin's Q, while this effect tends to be more stronger in group affiliated firms.

$H_{3}$ : There is a presence of significant association between FO and FP.

Another ownership pattern exists in corporate OS is the inclusion of various institutional investors. The empirical study of Hutchinson, Seamer, and Chapple (2015) showed a direct association of institutional ownership (IO) with FP. Mishra and Kapil (2017) also reported positive association between IO and Tobin's Q, however, IO has no influence on ROA. Contrarily, the study of Shahwan (2015) showed that the IO has no relationship with the VBF. Javid and Iqbal (2010) also reported no any association of institutional investors with FP of Pakistanis non-financial firms.

$H_{4}$ : There is a significant association exists between $I O$ and FP.

Corporate ownership (CO) also exists in the relationship between $\mathrm{CG}$ and FP. Ciftci et al. (2019) examined the cross (corporate) ownership with FP and reported an insignificant positive association of cross ownership with Tobin's Q. Furthermore, they also reported an inverse association of $\mathrm{CO}$ with ROA.

$H_{5}$ :There is a significant relationship exists between $C O$ and FP.

Theoretically, family ownership (FAMO) is considered beneficial for better monitoring as well as for greater resource provision for a business firm (both agency and resource dependency perspective, respectively). However, empirical evidence showed mixed findings on the above mentioned relationship. Yu-Thompson, Lu-Andrews, and Fu (2016) found a positive link between FAMO and FP. The study of Javid and Iqbal (2010) examined direct relationship of family ownership with ROA, ROE and Tobin's Q. Contrarily, Jameson et al. (2014) reported negative relationship between FAMO and Tobin's Q ratio of the Indian firms. Furthermore, Abdullah, Shah, Gohar, and Iqbal (2011) examined the performance of family and non-family BF in Pakistan and found that no significant difference in performance results of family owned and non-family owned firms.

$H_{6}$ :There is a significant relationship between $F O$ and FP.

Directors' ownership (DO) variable has also been studied over the years to find its association with performance of corporate sector. DO has positive association with FP as 
Bhagat and Bolton (2013) documented that there was a direct relationship between FP and DO Furthermore, Bhagat and Bolton (2013) also found a significant direct association between DO and FP measured through ROA and Tobin's Q of S\&P 1500 composite for the period of 1998 to 2016. Similarly, Javid and Iqbal (2010) also reported a direct association between ROE, ROA, Tobin's Q and DO of non-financial firms of Pakistan. However, the study of Makki, Abdul, and Lodhi (2013) found no association between FP and DO.

$H_{7}$ : A significant relationship exists between DO and FP.

Like the research results of other elements of OS, empirical evidence of business groupaffiliated (BGA) firms relating to FP is also inconclusive. Torres, Bertín, and LópezIturriaga (2017) studied the family and non-family Chilin firms with moderating role of BGA and they found a significant direct association of BGA with FP which was valued through Tobin's Q. In contrast, Bertrand et al. (2008) revealed a statistically inverse relationship between performance of Thai firms and BGA. Additionally, Abdullah et al. (2011) studied the sample of associated companies ownership and non-associated companies ownership in Pakistan and compared the results and found no statistical difference in the performance of the group affiliated companies and non-associated companies.

$H_{8}$ : There is a significant association present between BGA and FP.

Past empirical studies relating to Government ownership (GO) and FP also confined to indecisive results. Some researchers reported a direct association of GO and FP (Jiang, Laurenceson, \& Tang, 2008; Liao \& Young, 2012), while others documented negative relationship (Chen, Cheung, Stouraitis, \& Wong, 2005). Similarly Borisova, Brockman, Salas, and Zagorchev (2012) also found that the GO harms to CG and they also provided that value maximization is not always the priority of state ownership. Additionally, The study of Al-Janadi, Abdul Rahman, and Alazzani (2016) found the moderating negative effect GO in the effectiveness of CG. RDT states that greater GO will enhance the ability of business firm to access to valuable state resources, and this may increase performance of business firms. Whereas, GO tends to cause weak monitoring and influence on the decisions of management and this may increase AP (of Grosman, Wright, \& Okhmatovskiy, 2016).

$H_{9}$ : There is a significant relationship exists between GO and FP.

Management ownership (MO) is also found to have mixed results with FP. The study results of Darko, Aribi, and Uzonwanne (2016) revealed that MO has a direct effect on Tobin's Q for the Ghanaian firms. However, Ahmed Sheikh, Wang, and Khan (2013) found a significant negative effect of MO on FP measured by EPS, ROA and market to book ratio. Shao (2018) applied Generalized Methods of Moments (GMM) and also found negative association between MO and Tobin's Q. From agency perspective, MO will enhance the monitoring function which will result in better FP.

$H_{10}$ : There is a presence of significant association between $M O$ and FP.

Certain firm-specific variables derived from the previous literature include firm age, firm size, leverage and asset tangibility have also been used in this study (Pillai \& Al-Malkawi, 
2018; Saini \& Singhania, 2018). Past studies relating to the above mentioned firm specific variables also found mixed findings. The study of Pillai and Al-Malkawi (2018) showed a significant inverse relationship of BF age, leverage with FP, whereas, a positive influence of asset tangibility and firm size on VBF was found by (Dah, 2016). However, Ducassy and Guyot (2017) found that with increase in asset tangibility, Tobin's Q of BF decreases. Pillai and Al-Malkawi (2018) showed an opposite effect of firm size on ROA and Tobin's Q for Bahrain, UAE and Kuwait. O'Connor and Byrne (2015) also reported an adverse relationship between firm size and profitability of Chinese listed companies. The results of Ducassy and Guyot (2017) showed a direct but insignificant linkage between Tobin's Q and leverage.

$H_{11}$ : There is a significant relationship between firm specific control variables and FP.

Firm age is used as an independent and control variable in the past studies (Pillai \& Al-Malkawi, 2018; Saini \& Singhania, 2018). Rafiq, Salim, and Smyth (2016) used firm age as moderating variable to test the relationship between research and development and FP. Newer firms lack experience, fewer external ties and less accessibility of resources. On the other hand, there may be less agency issues in newer firms as compared to older firms. The current study uses firm age as moderating variable between the relationship of OS and firm value. As to the best of researcher knowledge, no such type of study has been conducted in Pakistan by using these set of variables.

$H_{12}$ : Firm age significantly moderates the relationship between ownership structure and FP.

The above reviewed literature on OS reveals that, this internal CG element has shown inconclusive results in different parts of the world and there is still exists a gap in finding the relationship between OS and value of business firms. In Pakistani context, it seems that the available literature on OS include; OC, IO and FO (Abdullah et al., 2011), BO (Makki et al., 2013), and MO (Ahmed Sheikh et al., 2013). Majority of aforementioned studies have used FP as outcome variable (Azeem, Kouser, et al., 2013; Tahir, Sohail, Qayyam, \& Mumtaz, 2016). Furthermore, past studies have shown limited empirical evidences related to different other components of OS such as; FO, GO, CO, RO and BGA towards BF value. Inclusion of industry dummy and asset tangibility as control variables to examine the relationship between $\mathrm{CG}$ and VBF is also focused. Additionally, firm age as an interactive variable with OS and the findings in this respect also contributes to the existing body of literature.

\section{Methods}

To test the hypotheses developed in preceding section, data has been collected from audited annual reports of non-financial sector firms listed at PSX. The sample size is comprised of 135 firms (out of 575 firms) listed at PSX during the period of 2004 to 2017. The reasons for selecting a sample of 135 firms are mentioned below: 
1. Only those firms are selected which belongs to non-financial sector

2. It is mandatory that non-financial sector firms should be listed at PSX

3. Out of listed non-financial sector firms, only those firms are to be selected whose complete data set is available for the time period 2004-2017.

Table 1

\begin{tabular}{llcc}
\multicolumn{3}{l}{ Sector Wise Division of Sample } & \\
\hline Sr. no. & Sectors & Sample & Proportion \\
\hline 1 & Automobile Parts & 16 & $11.85 \%$ \\
2 & Cable and Electrical Goods & 4 & $2.96 \%$ \\
3 & Construction Sector & 11 & $8.15 \%$ \\
4 & Engineering & 5 & $3.70 \%$ \\
5 & Oil and Gas Sector & 10 & $7.41 \%$ \\
6 & Power Sector & 4 & $2.96 \%$ \\
7 & Telecom & 3 & $2.22 \%$ \\
8 & Food and Personal Care & 13 & $9.63 \%$ \\
9 & Sugar & 16 & $11.85 \%$ \\
10 & Pharma & 6 & $4.44 \%$ \\
11 & Synthetic and Rayon & 4 & $2.96 \%$ \\
12 & Textile Composite & 12 & $8.89 \%$ \\
13 & Chemicals & 17 & $12.59 \%$ \\
14 & Fertilizers & 4 & $2.96 \%$ \\
15 & Glass \& Ceramics & 5 & $3.70 \%$ \\
16 & Paper and Board & 5 & $3.70 \%$ \\
\hline
\end{tabular}

\section{Model Specification}

$$
\begin{array}{r}
R O A_{i t}=\beta_{0}+\beta_{1} O C_{i t}+\beta_{2} R O_{i t}+\beta_{3} F O_{i t}+\beta_{4} I O_{i t}+\beta_{5} C O_{i t}+\beta_{6} F A M O_{i t}+\beta_{7} G O_{i t}+ \\
\beta_{8} M O_{i t}+\beta_{9} D O_{i t}+\beta_{10} B G A_{i t}+\beta_{11} I C_{i t}+\beta_{12} A G E_{i t}
\end{array}
$$

$$
\begin{gathered}
R O A_{i t}=\beta_{0}+\beta_{1} O C_{i t}+\beta_{2} R O_{i t}+\beta_{3} F O_{i t}+\beta_{4} I O_{i t}+\beta_{5} C O_{i t}+\beta_{6} F A M O_{i t}+\beta_{7} G O_{i t}+ \\
\beta_{8} M O_{i t}+\beta_{9} D O_{i t}+\beta_{10} B G A_{i t}+\beta_{11} I C_{i t}+\beta_{12} A G E_{i t}+\beta_{13} O C * A G E_{i t}+\beta_{14} R O * A G E_{i t}+ \\
\beta_{15} F O * A G E_{i t}+\beta_{16} I O * A G E_{i t}+\beta_{17} C O * A G E_{i t}+\beta_{18} F A M O * A G E_{i t}+\beta_{19} G O * A G E_{i t}+ \\
\beta_{20} M O * A G E_{i t}+\beta_{21} D O * A G E_{i t}+\beta_{22} E B * A G E_{i t}+\beta_{23} B G A * A G E_{i t}+\mu_{i t} \\
R O E_{i t}=\beta_{0}+\beta_{1} O C_{i t}+\beta_{2} R O_{i t}+\beta_{3} F O_{i t}+\beta_{4} I O_{i t}+\beta_{5} C O_{i t}+\beta_{6} F A M O_{i t}+\beta_{7} G O_{i t}+ \\
\beta_{8} M O_{i t}+\beta_{9} D O_{i t}+\beta_{10} B G A_{i t}+\beta_{11} I C_{i t}+\beta_{12} A G E_{i t}+\mu_{i t}
\end{gathered}
$$




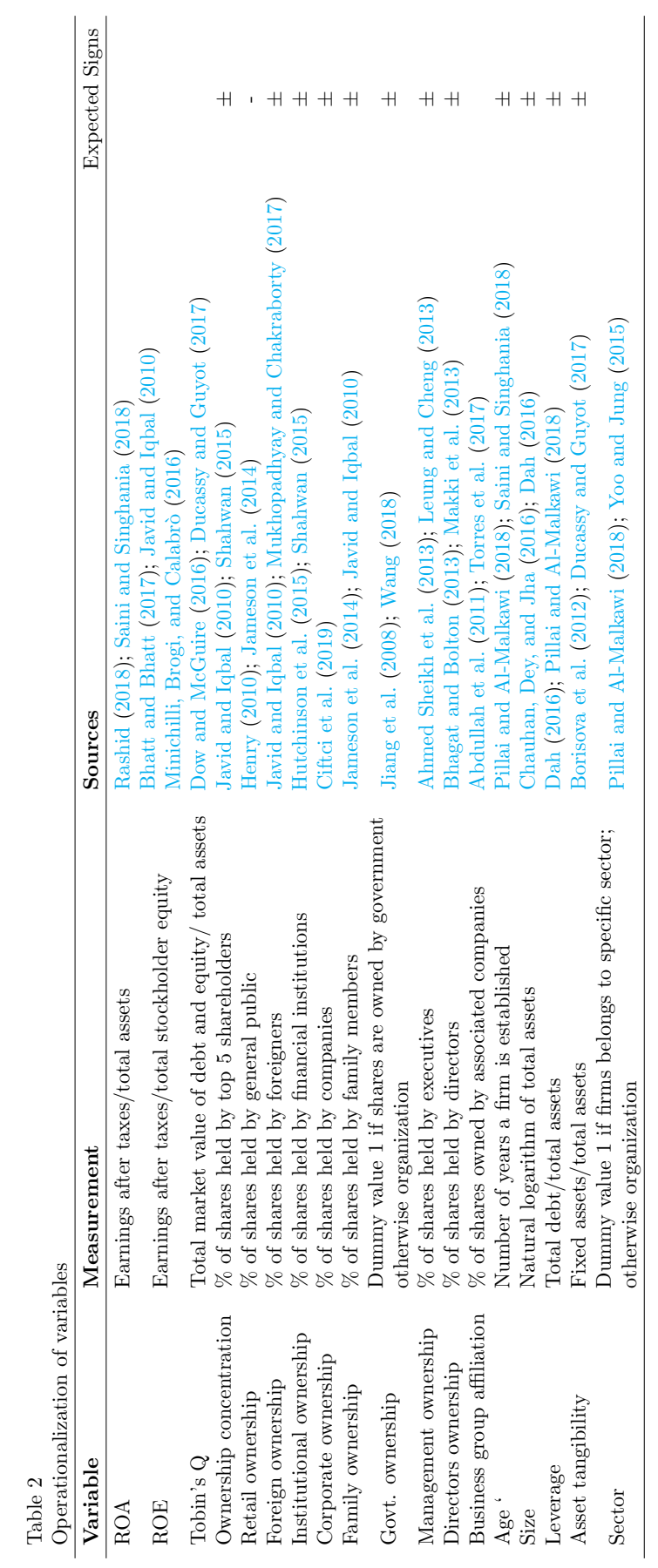




$$
\begin{gathered}
R O E_{i t}=\beta_{0}+\beta_{1} O C_{i t}+\beta_{2} R O_{i t}+\beta_{3} F O_{i t}+\beta_{4} I O_{i t}+\beta_{5} C O_{i t}+\beta_{6} F A M O_{i t}+\beta_{7} G O_{i t}+ \\
\beta_{8} M O_{i t}+\beta_{9} D O_{i t}+\beta_{10} B G A_{i t}+\beta_{11} I C_{i t}+\beta_{12} A G E_{i t}+\beta_{13} O C * A G E_{i t}+\beta_{14} R O * A G E_{i t}+ \\
\beta_{15} F O * A G E_{i t}+\beta_{16} I O * A G E_{i t}+\beta_{17} C O * A G E_{i t}+\beta_{18} F A M O * A G E_{i t}+\beta_{19} G O * A G E_{i t}+ \\
\beta_{20} M O * A G E_{i t}+\beta_{21} D O * A G E_{i t}+\beta_{22} E B * A G E_{i t}+\beta_{23} B G A * A G E_{i t}+\mu_{i t}
\end{gathered}
$$

$$
\begin{array}{r}
T B Q_{i t}=\beta_{0}+\beta_{1} O C_{i t}+\beta_{2} R O_{i t}+\beta_{3} F O_{i t}+\beta_{4} I O_{i t}+\beta_{5} C O_{i t}+\beta_{6} F A M O_{i t}+\beta_{7} G O_{i t}+ \\
\beta_{8} M O_{i t}+\beta_{9} D O_{i t}+\beta_{10} B G A_{i t}+\beta_{11} I C_{i t}+\beta_{12} A G E_{i t}+\mu_{i t}
\end{array}
$$

$$
\begin{gathered}
T B Q_{i t}=\beta_{0}+\beta_{1} O C_{i t}+\beta_{2} R O_{i t}+\beta_{3} F O_{i t}+\beta_{4} I O_{i t}+\beta_{5} C O_{i t}+\beta_{6} F A M O_{i t}+\beta_{7} G O_{i t}+ \\
\beta_{8} M O_{i t}+\beta_{9} D O_{i t}+\beta_{10} B G A_{i t}+\beta_{11} I C_{i t}+\beta_{12} A G E_{i t}+\beta_{13} O C * A G E_{i t}+\beta_{14} R O * A G E_{i t}+ \\
\beta_{15} F O * A G E_{i t}+\beta_{16} I O * A G E_{i t}+\beta_{17} C O * A G E_{i t}+\beta_{18} F A M O * A G E_{i t}+\beta_{19} G O * A G E_{i t}+ \\
\beta_{20} M O * A G E_{i t}+\beta_{21} D O * A G E_{i t}+\beta_{22} E B * A G E_{i t}+\beta_{23} B G A * A G E_{i t}+\mu_{i t}
\end{gathered}
$$

In the above models, ROA refers to return on assets, ROE refers to return on equity, TBQ refers to Tobin's Q. The proxies of OS are: OC refers to ownership concentration, RO refers to retail ownership, FO refers to foreign ownership, IO refers to institutional ownership, CO refers to corporate ownership, FAMO refers to family ownership, GO refers to government ownership, MO refers to management ownership, DO refers to directors ownership, BGA refers to business group affiliation, IC refers to internal characteristics of the firms such as size, leverage, asset tangibility i refers to firm, and t refers to time.

\section{Results and Discussion}

Table 1 shows the summary statistics of the variables based on the sample. Accounting based performance, as measured in terms of profitability, denotes that on average nonfinancial sector firms are earning $7.236 \%$ and $14.828 \%$ by utilizing their assets and equity respectively. Market based performance, as measured in terms of Tobin's Q, shows that market value of debt and equity is 1.519 times higher than book value of debt and equity. Average score of OC demonstrate that top five shareholders captures $64.5 \%$ of the total equity; though in certain circumstances, this proportion can extend up to $99.289 \%$. Average shares owned by general public, well-known as RO, constitutes $28.262 \%$ of the total equity of firms.

The mean score of $\%$ of FO in total equity of firms is $6.988 \%$. Percentage of shares held by financial institutions are $12.564 \%$ of total equity of firms on average. Investment of corporate sector constitutes $8.149 \%$ of equity in non-financial sector firms. Percentage of shares held by family members of board of directors captures $15.457 \%$ of equity. Average 
shares owned by directors are $12.191 \%$ of the total shares in non-financial sector firms. Business group affiliation, measured in terms of shares held by associated companies, captures $30.92 \%$ of firm's equity. The summary statistics reveals that firms where GO exist constitute $35.34 \%$ of the total sample. MO shows that executives captures $0.241 \%$ share in total ownership of firms included in sample.

After gauging the behavior of data based on sample, researcher has applied Pearson correlation to assess the degree and strength of relationship among variables.

\begin{tabular}{lcccc}
$\begin{array}{l}\text { Table } 3 \\
\text { Descriptive Statistics }\end{array}$ & & & \\
\hline Variable & Mean & Std. Dev. & Min & Max \\
\hline ROA & 7.236 & 9.136 & -27.004 & 67.959 \\
ROE & 14.828 & 30.209 & -279.187 & 446.443 \\
Tobin's Q & 1.519 & 1.404 & -2.383 & 16.444 \\
OC & 64.507 & 19.374 & 11.76 & 99.289 \\
RO & 28.262 & 22.7 & 0.112 & 99.086 \\
FO & 6.988 & 16.389 & 0.000 & 89.101 \\
IO & 12.564 & 11.808 & 0.000 & 88.556 \\
CO & 8.149 & 15.88 & 0.000 & 90.393 \\
FAMO & 15.457 & 22.026 & 0.000 & 98.393 \\
DO & 12.191 & 16.824 & 0.000 & 98.775 \\
BGA & 30.92 & 30.135 & 0.000 & 99.098 \\
GO & 0.353 & 0.478 & 0.000 & 1.000 \\
MO & 0.368 & 0.482 & 0.000 & 1.000 \\
Age & 36.474 & 19.849 & 3.000 & 156 \\
Size & 9.689 & 0.717 & 7.494 & 11.797 \\
Leverage & 52.483 & 22.808 & 0.050 & 222.738 \\
Asset_Tang & 42.721 & 22.299 & 0.006 & 99.087 \\
\hline
\end{tabular}

\section{Correlation among Variables}

The results of correlation matrix, as presented in Table 4, show that all variables are significantly associated with ROA at conventional levels of significance. The results of all variables with ROE show that all dimensions of ownership structure except IO are significantly correlated with ROE. Tobin's Q, a measure of market performance, is significantly associated with various dimensions of OS.

\section{Multiple Regression Analysis}

To gauge the role of various dimensions of ownership structure in financial performance of firms; researcher has applied multiple regression analysis by adding age as moderating variable. A panel of 14 years belonging to 16 non-financial industries has been empirically studied. This study compares the accounting based performance with market based performance using proxies of ROA, ROE (for former) and Tobin's Q (for later). The data contains heteroscedasticity, autocorrelation and cross-sectional dependence. To address these issues, the researcher has employed Panel Corrected Standard Error (PCSE) model. This model is applied when $\mathrm{N}$ is greater than $\mathrm{T}$ (Hoechle, 2007). 


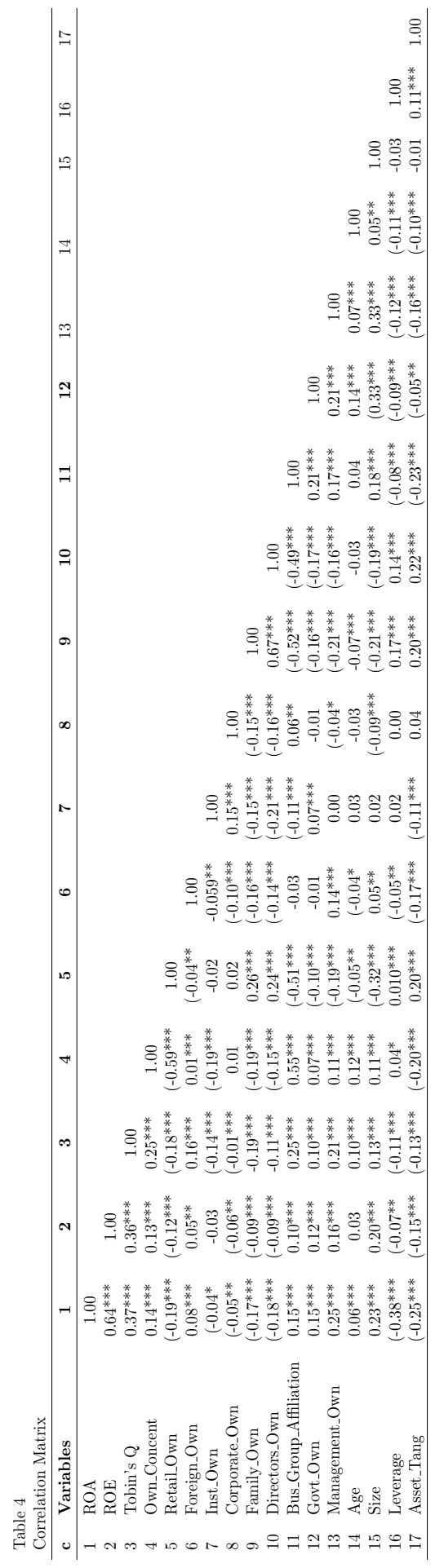


Table 5

Causal Relationship between Ownership Structure and Business Firm Performance

\begin{tabular}{|c|c|c|c|}
\hline Variables & $\begin{array}{c}\text { (Model 1) } \\
\text { ROA }\end{array}$ & $\begin{array}{l}\text { (Model 2) } \\
\text { ROE }\end{array}$ & $\begin{array}{l}\text { (Model 3) } \\
\text { Tobin's Q }\end{array}$ \\
\hline \multirow[t]{2}{*}{$\mathrm{OC}$} & $0.0456^{*}$ & $0.276^{* * *}$ & $0.00903^{* *}$ \\
\hline & -0.0273 & -0.0927 & -0.00437 \\
\hline \multirow[t]{2}{*}{ RO } & $-0.0455^{* * *}$ & 0.0315 & $0.00674^{* *}$ \\
\hline & -0.0168 & -0.0687 & -0.00305 \\
\hline \multirow[t]{2}{*}{ FO } & $-0.0525^{* *}$ & -0.0797 & $0.0101^{* *}$ \\
\hline & -0.0232 & -0.0697 & -0.00417 \\
\hline \multirow[t]{2}{*}{ IO } & 0.0412 & $0.351^{* *}$ & 0.00821 \\
\hline & -0.0346 & -0.148 & -0.0067 \\
\hline \multirow[t]{2}{*}{$\mathrm{CO}$} & 0.0336 & 0.0719 & -0.00298 \\
\hline & -0.0258 & -0.0882 & -0.00322 \\
\hline \multirow[t]{2}{*}{ FAMO } & -0.0106 & -0.0125 & $-0.00581^{*}$ \\
\hline & -0.0202 & -0.0819 & -0.00352 \\
\hline \multirow[t]{2}{*}{ DO } & $-0.0885^{* * *}$ & -0.174 & 0.00143 \\
\hline & -0.0285 & -0.117 & -0.00341 \\
\hline \multirow[t]{2}{*}{ BGA } & $-0.102^{* * *}$ & $-0.289^{* * *}$ & -0.00251 \\
\hline & -0.0133 & -0.062 & -0.00391 \\
\hline \multirow[t]{2}{*}{ GO } & $-1.607^{* *}$ & -1.299 & 0.0321 \\
\hline & -0.683 & -2.782 & -0.0965 \\
\hline \multirow[t]{2}{*}{ MO } & $-0.906^{* *}$ & $-2.120^{*}$ & -0.0516 \\
\hline & -0.406 & -1.222 & -0.0349 \\
\hline \multirow[t]{2}{*}{ Size } & $2.221 * * *$ & $7.604^{* * *}$ & $0.194 * * *$ \\
\hline & -0.447 & -1.525 & -0.0615 \\
\hline \multirow[t]{2}{*}{ Leverage } & $-0.136^{* * *}$ & $-0.0829^{*}$ & $-0.00405^{* *}$ \\
\hline & -0.0145 & -0.0459 & -0.00158 \\
\hline \multirow[t]{2}{*}{ Asset_Tang } & $-0.0773^{* * *}$ & $-0.200^{* * *}$ & $5.11 \mathrm{E}-05$ \\
\hline & -0.0139 & -0.0437 & -0.00171 \\
\hline \multirow[t]{2}{*}{ Auto } & $5.414^{* * *}$ & $9.942^{* * *}$ & $0.629 * * *$ \\
\hline & -1.075 & -3.142 & -0.177 \\
\hline \multirow[t]{2}{*}{ Electrical } & -0.272 & -3.607 & $0.246^{*}$ \\
\hline & -1.04 & -3.411 & -0.139 \\
\hline \multirow[t]{2}{*}{ Construction } & $4.172^{* *}$ & 6.843 & $0.366^{* * *}$ \\
\hline & -1.64 & -4.22 & -0.0859 \\
\hline \multirow[t]{2}{*}{ Engineering } & 1.378 & 3.557 & $0.231^{* * *}$ \\
\hline & -0.997 & -3.157 & -0.0838 \\
\hline \multirow[t]{2}{*}{ Oil \& Gas } & $3.907^{* * *}$ & 1.669 & $0.552^{* * *}$ \\
\hline & -1.18 & -3.467 & -0.148 \\
\hline \multirow[t]{2}{*}{ Power } & 0.9 & 2.689 & 0.087 \\
\hline & -1.233 & -3.436 & -0.0954 \\
\hline Telecom & $-2.323^{* *}$ & $-9.634^{* * *}$ & -0.00237 \\
\hline & -1.005 & -2.706 & -0.0998 \\
\hline Food & $6.715^{* * *}$ & $21.60^{* * *}$ & $1.992^{* * *}$ \\
\hline & -1.258 & -5.206 & -0.318 \\
\hline Sugar & $3.021^{* *}$ & 4.972 & $0.431 * * *$ \\
\hline & -1.197 & -3.788 & -0.0883 \\
\hline Pharma & $5.698^{* * *}$ & $8.188^{* * *}$ & $1.366^{* * *}$ \\
\hline & -1.213 & -2.929 & -0.275 \\
\hline Synthetic & -1.488 & -4.533 & 0.16 \\
\hline & -1.651 & -3.958 & -0.105 \\
\hline Textile & 2.195 & 5.779 & $0.188^{* *}$ \\
\hline & -1.455 & -3.662 & -0.0938 \\
\hline Chemicals & $3.027^{* *}$ & 3.877 & $0.616^{* * *}$ \\
\hline & -1.232 & -3.174 & -0.13 \\
\hline Fertilizer & $6.628^{* * *}$ & $29.68 * * *$ & $1.793^{* * *}$ \\
\hline & -1.741 & -8.709 & -0.481 \\
\hline Glass \& Ceramics & 1.65 & $16.93^{* * *}$ & $0.638 * * *$ \\
\hline & -1.072 & -6.549 & -0.142 \\
\hline
\end{tabular}


Table 5

Contd.

\begin{tabular}{lccc}
\hline Variables & $\begin{array}{c}\text { Model 1) } \\
\text { ROA }\end{array}$ & $\begin{array}{c}\text { (Model 2) } \\
\text { ROE }\end{array}$ & $\begin{array}{c}\text { (Model 3) } \\
\text { Tobin's Q }\end{array}$ \\
\hline Age & $-0.153^{* *}$ & -0.21 & 0.000609 \\
& -0.0624 & -0.212 & -0.00841 \\
OC_AGE & 0.000237 & -0.000164 & $-2.97 \mathrm{E}-05$ \\
& -0.000727 & -0.00237 & -0.000124 \\
RO_AGE & $0.00129^{* * *}$ & 0.00193 & $-9.36 \mathrm{E}-05$ \\
& -0.000362 & -0.00145 & $-7.84 \mathrm{E}-05$ \\
FO_AGE & 0.000688 & -0.0015 & -0.000105 \\
& -0.000692 & -0.00187 & $-9.75 \mathrm{E}-05$ \\
IO_AGE & $-0.00202^{* *}$ & $-0.0106^{* * *}$ & $-0.000429^{* * *}$ \\
& -0.000816 & -0.00341 & -0.000153 \\
CO_AGE & $-0.00140^{*}$ & $-0.00507^{* *}$ & $-7.67 \mathrm{E}-05$ \\
& -0.000825 & -0.00245 & -0.000119 \\
FAM_AGE & 0.000109 & -0.000493 & $-3.25 \mathrm{E}-05$ \\
& -0.000445 & -0.00177 & $-9.24 \mathrm{E}-05$ \\
DO_AGE & 0.000783 & 0.000481 & $9.33 \mathrm{E}-06$ \\
& -0.000598 & -0.00264 & $-9.92 \mathrm{E}-05$ \\
BGA_AGE & $0.00184^{* * *}$ & $0.00538^{* * *}$ & $0.000213^{*}$ \\
& -0.000434 & -0.0015 & -0.000109 \\
GO_AGE & $0.0669^{* * *}$ & $0.128^{* *}$ & 0.00272 \\
& -0.0159 & -0.0651 & -0.00257 \\
MO_AGE & $0.0260^{* *}$ & $0.0610^{*}$ & $0.00266^{* *}$ \\
& -0.0107 & -0.0355 & -0.00108 \\
Constant & -2.883 & $-59.67^{* * *}$ & $-1.467^{*}$ \\
& -5.314 & -17.32 & -0.796 \\
R-squared & 0.322 & 0.151 & 0.292 \\
Wald Chi Square & $277892.57^{* * *}$ & $15864.70^{* * *}$ & $4695.70^{* * *}$ \\
\hline Standard errors in parentheses & & \\
$* * *$ p $<0.01, * *$ & $p<0.05 *$ p $<0.1$ & &
\end{tabular}

Table 5 shows the findings of regression analysis using PCSE model. As discussed earlier, researcher has compared accounting based performance (using ROA and ROE) with market performance (using Tobin's Q). The empirical findings derived from ROA (model 1) and ROE (model 2) show significant positive influence of OC on financial performance; which confirmed $H_{1}$ and is in agreement with studies conducted by Ehikioya (2009); Javid and Iqbal (2008). The positive coefficient value implies that shareholders having majority of firms shares actively participate in decision making process; thus improving short-term FP. The role of RO in explaining financial performance is significant negative in ROA model; which is in agreement with existing study conducted by Elghouti (2014). However, in ROE model RO has positive but insignificant effect on financial performance; which is inconsistent with the findings of Elghouti (2014) who examined this relationship in the context of Egyptian firms. Therefore, $\mathrm{H}_{2}$ is partially confirmed due to the difference in contextual factor of Egypt, the findings may not be applicable in the context of Pakistan.

The contribution of FO in ROA is found significant negative; which shows that increase in number of shares held by foreign shareholders is not beneficial for accounting based FP. This finding is supported by Abor and Biekpe (2007). The findings of ROE model shows negative but insignificant influence of FO owing to the fact that Pakistani investors do not consider foreigner part in firm's equity ownership while making any investment decisions; which is in line with existing study (Ongore, 2011). Therefore, $H_{3}$ related to significant influence of FO on accounting based performance is partially confirmed. IO is found to 
have significant and positive role in financial performance of firms; which confirmed $H_{4}$ and is in light with existing literature (Kao, Hodgkinson, \& Jaafar, 2019; Mishra \& Kapil, 2017). The positive coefficient value of IO implies that increase in share of IO can enhance the short-term financial performance of non-financial sector firms.

The relationship between $\mathrm{CO}$ and financial performance is found negative and insignificant; which is contradictory with a single study conducted in this area by Ciftci et al. (2019). Therefore, $H_{6}$ is not confirmed. This implies that firms where significant majority of shares are occupied by family members; they can harm performance of firms by making centralized decisions. This finding is validated by the study of Chen et al. (2005).

The role of DO in performance of firms is found significant negative which is confirmed by $H_{7}$ and is consistent with existing literature (Ehikioya, 2009). This implies that firms where significant number of shares are held by board of directors can exploit the rights of minority shareholders. This in-turn harm the financial performance of firms by creating agency issues. The influence of business group affiliation on short-term performance of firms is found significant negative which supports $H_{8}$ and is confirmed by the study of Shyu (2013). Shares owned by group of legally independent firms increase agency issues which raises agency costs; thus leading to harm short term performance of firms.

The effect of GO is found significant negative in ROA model which is confirmed by Liao and Young (2012). Whereas, GO is found to have no influence on ROE of firms at any conventional level of significance. Therefore, is partially confirmed (confirmed in case of ROA and not confirmed in case of ROE).

The firms' specific characteristics such as size, leverage and asset tangibility significantly contribute towards financial performance of firms; as supported by existing body of literature (Abor \& Biekpe, 2007; Kao et al., 2019). Thus $H_{11}$ is confirmed. Moreover, researchers have also controlled sector wise influence in ascertaining the relationship between OS and short-term performance of firms.

Age, as interacting variable, has negative influence in the short term performance which is supported by the study of Saini and Singhania (2018). The interaction of age with various dimensions of OS is found to have significant role in financial performance of firms. $\mathrm{RO}$ with age (as interacting variable) has positive role in firm's short term performance measured in terms of ROA; which shows that well established firms having significant shares held by general public perform better than newly established firms. IO_Age has negative influence on FP which is statistically significant at 5\% level; suggesting that the effect of IO on accounting based performance is observed weaker in older firms. Similarly, the role of CO_Age in short term performance is also observed significant negative; which recommends stronger negative influence of $\mathrm{CO}$ in short term performance.

BGA with interaction of age has positive influence in performance of firms; which demonstrates that the effect of group affiliation is stronger in well-established firm's performance. GO_Age has significant positive role in performance; which demonstrates that GO influence short-term performance of older firms. MO with age as interacting variable is found to have positive contribution in the financial performance of firms. The positive coefficient value of MO_Age suggest that effect of shares held by executives is observed to be stronger in accounting based performance of well-established firms. This study could not find any impact of rest of interacting variables in short term performance of firms. 
Therefore, $H_{12}$ is partially confirmed. Researchers could not find any empirical evidence to support the conditional role of age in the relationship between OS and accounting based performance of firms. Therefore, this anomaly need to be further explored in future research.

The explanatory power of this model is shown by $\mathrm{R}$ square; which shows that OS structure can explain $32.2 \%$ variability in ROA and $15.1 \%$ variation in ROE. The overall significance of ROA and ROE models have been demonstrated by Wald Chi Square, which confirms the validity of both model.

Model 3 of table 5 presents the results on evaluation of various dimensions of OS based on Tobin's Q. The effect of OC on long-run performance is found significant as well as positive; which states that shareholders having largest proportion in the equity of firms take active part in the decision making of firms. Relationship between OC and Tobin's Q supports $H_{1}$ and is confirmed by existing studies (Al-Sa'eed et al., 2018; Javid \& Iqbal, 2010).

The role of $\mathrm{RO}$ is found significant positive; which confirms $\mathrm{H}_{2}$ and is inconsistent with existing studies (Jameson et al., 2014; Jiang et al., 2008). This demonstrates that individual shareholders are satisfied with the policies and return earned on their investments. They prefer to retain shares of such firms in the long run. The role of FO is found significant positive in Tobin's Q; which is validated by existing literature (Anum Mohd Ghazali, 2010). Thus $H_{3}$ is confirmed and the positive coefficient value implies that increase in shares held by foreign stockholders is beneficial in improving long-run performance of firms.

Researchers have found no contribution of IO in explaining long term performance of firms as confirmed by Shahwan (2015). Therefore, $H_{4}$ is not confirmed. CO is found to have negative effect on Tobin's Q of firms; which is not significant at any level thus, $H_{5}$ is also not confirmed. This finding is contradictory with the study conducted by Ciftci et al. (2019). As to the best of authors knowledge, only a single study has investigated this relationship; future research is needed to clarify this relationship.

The effect of FAMO is found significant negative on the long-run performance of firms; which confirms $H_{6}$ and is in agreement with the findings of existing literature (Kao et al., 2019). The reason behind negative relationship is strict controlling and monitoring of family owned firms; which do not align with the interest of minority shareholders. The misalignment of interest creates agency issues; which require considerable cost. The role of DO in explaining the long run performance of firms is positive but insignificant; which fails to confirm $H_{7}$ and is in line with existing literature (Ehikioya, 2009). This study has found negative insignificant contribution of BGA in market performance of firms; which is confirmed by Malan, Salamudin, and Ahmad (2014). This finding fails to confirm

Besides various dimensions of OS, researchers have used some control variables; such as size leverage and asset tangibility. In these variables, researchers have found significant role of size and leverage in the long-run performance of firms which confirm $H_{11}$. Existing studies support these findings (Saini \& Singhania, 2018). Besides firms specific characteristics, researcher has also controlled the effect of sectors included in the study. This paper has also investigated the interacting role of age in the relationship between OS and market performance. The interaction of age with IO has significant negative role in long run performance of firms; which demonstrates that IO negatively affects financial 
performance in older firms. This implies that the older firms have more agency issues than newer firms. The interacting role of age with BGA is found significant positive in the market performance of firms; which states that group affiliated firms perform better than well-established firms. MO with interaction of age is found to have significant positive role in the long-run performance. The positive value of MO_Age demonstrates that older firms with significant number of shares owned by executives have strong influence on market performance of firms. Rest of the dimensions of OS with age have statistically no influence in firm's long-run performance. Therefore $H_{12}$ is partially confirmed. Researchers could not find any empirical evidence to support the interactive role of age in the relationship between OS and VBF. Therefore, this area need to be further explored in future research.

The value of $\mathrm{R}$ square is $29.2 \%$ which demonstrates variability explained by OS in longrun performance of firms. The score of Wald Chi Square is 4695.70, which is statistically significant showing that model applied is valid.

Table 6

Summary of Hypotheses

\begin{tabular}{|c|c|c|c|}
\hline & Hypotheses & $\begin{array}{l}\text { Accounting Based } \\
\text { Performance }\end{array}$ & $\begin{array}{l}\text { Market Based } \\
\text { Performance }\end{array}$ \\
\hline$H_{1}$ & $\begin{array}{l}\text { There is significant relationship between ownership concentration } \\
\text { and firm performance. }\end{array}$ & Confirmed & Confirmed \\
\hline $\mathrm{H}_{2}$ & $\begin{array}{l}\text { There is significant relationship between retail ownership and firm } \\
\text { performance. }\end{array}$ & Partially Confirmed & Confirmed \\
\hline$H_{3}$ & $\begin{array}{l}\text { There is significant relationship between foreign ownership and } \\
\text { business firm performance. }\end{array}$ & Partially Confirmed & Confirmed \\
\hline$H_{4}$ & $\begin{array}{l}\text { There is significant association between institutional ownership } \\
\text { and performance of business firms. }\end{array}$ & Partially Confirmed & Not Confirmed \\
\hline$H_{5}$ & $\begin{array}{l}\text { There is significant relationship between corporate ownership and } \\
\text { firm performance. }\end{array}$ & Not Confirmed & Not Confirmed \\
\hline$H_{6}$ & $\begin{array}{l}\text { There is significant relationship between family ownership and } \\
\text { firm performance. }\end{array}$ & Not Confirmed & Confirmed \\
\hline$H_{7}$ & $\begin{array}{l}\text { There is significant relationship between directors ownership } \\
\text { and firm performance. }\end{array}$ & Partially Confirmed & Not Confirmed \\
\hline$H_{8}$ & $\begin{array}{l}\text { There is significant relationship between business group affiliation } \\
\text { and firm performance. }\end{array}$ & Confirmed & Not Confirmed \\
\hline$H_{9}$ & $\begin{array}{l}\text { There is significant relationship between Govt. ownership and } \\
\text { performance of business firms. }\end{array}$ & Partially Confirmed & Not Confirmed \\
\hline$H_{10}$ & $\begin{array}{l}\text { There is significant relationship between management ownership } \\
\text { and firm performance. }\end{array}$ & Confirmed & Not Confirmed \\
\hline$H_{11}$ & $\begin{array}{l}\text { There is significant relationship between firm specific control } \\
\text { variables and firm performance }\end{array}$ & Confirmed & Partially Confirmed \\
\hline$H_{12}$ & $\begin{array}{l}\text { Age significantly moderates in the relationship between ownership } \\
\text { structure and firm performance. }\end{array}$ & Partially Confirmed & Partially Confirmed \\
\hline
\end{tabular}

\section{Conclusion and Implications}

The relationship between OS and VBF has widely been studied in developed economies of the world. A review of literature related to Pakistan shows no empirical evidence related to various aspects of ownership structure namely; GO, CO, RO BGA and their inter-relationship with FP. Additionally, interactive role of age has not been investigated thoroughly in aforesaid relationship. This paper aims at bridging the identified gap by investigating the role of various dimensions of OS in FP of non-financial sector firms with 
comprehensive data set comprising of 135 firms during the period of 2004 to 2017. Two aspects of financial performance have been studied namely; accounting based and market based performance. A comparison between both aspects of performance has also been made. The findings of this paper offer insights related to various categories of shareholders, such as associated companies, executives and public sector companies; that may have implication for short term performance of well established firms.

The positive role of associated and public sector companies favors RDT; which implies better availability and utilization of resources. Moreover, well established firms has lesser agency issues than newly established firms when relationship between MO and financial performance is examined. As per findings of this study, IO and CO harm accounting based performance of new firms. Negative role of CO and IO highlight presence of type II agency problems that exist between large and minority shareholders. Therefore, newly established non-financial sector firms should consider this fact accordingly.

Findings in the context of long run performance of firms reveal that well established firms should prioritize ownership of associated companies and executives. Associated companies have influence in resolution of type I agency issues between shareholders and management in the long-run; which support AT. Investors perceive it as availability of greater resources; giving them confidence which ultimately improves performance of firms in the market. The affirmative role of MO indicates that well established firms can more easily resolve their agency issues in the long run than newly established firms. The management of newly established firms should also take into consideration the existence of type I agency problems when IO is present. The comparative analysis reveals that various dimensions of OS can better explain accounting base performance rather than market based performance in the presence of age as moderator. Furthermore, in the discussion part of the article, it is provided that the confirmation/partially confirmation of hypothesis developed in the study are in line with the results of previous studies. As per above mentioned discussion, it can be recommended that policy makers, like SECP, need to set rules regarding various dimensions of ownership structure in the best interest of investors and other stakeholders. Also, in order to achieve wealth maximization goal, investors should invest in shares of such companies where less agency issues exist and available resources are better utilized.

Despite author's best efforts, some uncontrolled deficiencies have been observed. Researcher has primarily focused on OS; whereas other aspects of CG namely; board structure, audit structure and compensation structure have not been considered. Market performance is measured in terms of Tobin's Q; potential scholars can measure it by taking stock returns as well. Other measures of performance such as economic value added (EVA) and relative efficiency of firms can also be taken into consideration. A comparison between firm's performance during era of pre and post CG code revision 2012 can also be done using comprehensive dataset. Interactive role of various dimensions of OS is also recommended for potential scholars. 


\section{References}

Abdullah, F., Shah, A., Gohar, R., \& Iqbal, A. M. (2011). The effect of group and family ownership on firm performance: Empirical evidence from Pakistan. International Review of Business Research Papers, 7(4), 191-208.

Abor, J., \& Biekpe, N. (2007). Corporate governance, ownership structure and performance of SMEs in Ghana: Implications for financing opportunities. Corporate Governance: The International Journal of Business in Society, 7(3), 288-300.

Ahmed Sheikh, N., Wang, Z., \& Khan, S. (2013). The impact of internal attributes of corporate governance on firm performance: Evidence from Pakistan. International Journal of Commerce and Management, 23(1), 38-55.

Al-Janadi, Y., Abdul Rahman, R., \& Alazzani, A. (2016). Does government ownership affect corporate governance and corporate disclosure? Evidence from Saudi Arabia. Managerial Auditing Journal, 31(8/9), 871-890.

Al-Sa'eed, M. A., et al. (2018). The impact of ownership structure and dividends on firm's performance: Evidence from manufacturing companies listed on the amman stock exchange. Australasian Accounting, Business and Finance Journal, 12(3), 87-106.

Anum Mohd Ghazali, N. (2010). Ownership structure, corporate governance and corporate performance in Malaysia. International Journal of Commerce and Management, 20(2), 109-119.

Azeem, M., Kouser, R., et al. (2013). Impact of quality corporate governance on firm performance: A ten year perspective. Pakistan Journal of Commerce and Social Sciences (PJCSS), 7(3), 656-670.

Bertrand, M., Johnson, S., Samphantharak, K., \& Schoar, A. (2008). Mixing family with business: A study of Thai business groups and the families behind them. Journal of Financial Economics, 88(3), 466-498.

Bhagat, S., \& Bolton, B. (2013). Director ownership, governance, and performance. Journal of Financial and Quantitative Analysis, 48(1), 105-135.

Bhatt, P. R., \& Bhatt, R. R. (2017). Corporate governance and firm performance in Malaysia. Corporate Governance: The International Journal of Business in Society, $17(5), 896-912$.

Borisova, G., Brockman, P., Salas, J. M., \& Zagorchev, A. (2012). Government ownership and corporate governance: Evidence from the EU. Journal of Banking $\&$ Finance, $36(11), 2917-2934$.

Boyd, B. K., Gove, S., \& Solarino, A. M. (2017). Methodological rigor of corporate governance studies: A review and recommendations for future studies. Corporate Governance: An International Review, 25(6), 384-396.

Chauhan, Y., Dey, D. K., \& Jha, R. R. (2016). Board structure, controlling ownership, and business groups: Evidence from India. Emerging Markets Review, 27, 63-83.

Chen, Z., Cheung, Y.-L., Stouraitis, A., \& Wong, A. W. (2005). Ownership concentration, firm performance, and dividend policy in Hong Kong. Pacific-Basin Finance Journal, 13(4), 431-449.

Chhillar, P., \& Lellapalli, R. V. (2015). Divergence or convergence: Paradoxes in corporate governance? Corporate Governance, 15(5), 693-705. 
Ciftci, I., Tatoglu, E., Wood, G., Demirbag, M., \& Zaim, S. (2019). Corporate governance and firm performance in emerging markets: Evidence from Turkey. International Business Review, 28(1), 90-103.

Claessens, S., \& Yurtoglu, B. B. (2013). Corporate governance in emerging markets: A survey. Emerging Markets Review, 15, 1-33.

Cueto, D. C., \& Switzer, L. N. (2015). Intraday market liquidity, corporate governance, and ownership structure in markets with weak shareholder protection: Evidence from Brazil and Chile. Journal of Management \& Governance, 19(2), 395-419.

Dah, M. A. (2016). Governance and firm value: The effect of a recession. Research in International Business and Finance, 37, 464-476.

Darko, J., Aribi, Z. A., \& Uzonwanne, G. C. (2016). Corporate governance: The impact of director and board structure, ownership structure and corporate control on the performance of listed companies on the Ghana stock exchange. Corporate Governance: The International Journal of Business in Society, 16(2), 259-277.

Denis, D. K., \& McConnell, J. J. (2003). International corporate governance. Journal of financial and quantitative analysis, 38(1), 1-36.

Detthamrong, U., Chancharat, N., \& Vithessonthi, C. (2017). Corporate governance, capital structure and firm performance: Evidence from Thailand. Research in International Business and Finance, 42, 689-709.

Dow, S., \& McGuire, J. (2016). Family matters?: A cross-national analysis of the performance implications of family ownership. Corporate Governance: An International Review, 24(6), 584-598.

Ducassy, I., \& Guyot, A. (2017). Complex ownership structures, corporate governance and firm performance: The french context. Research in International Business and Finance, 39, 291-306.

Ehikioya, B. I. (2009). Corporate governance structure and firm performance in developing economies: Evidence from Nigeria. Corporate Governance: The International Journal of Business in Society, 9(3), 231-243.

Elghouti, A. S. (2014). Effect of ownership structure on firm stock returns and financial performance: Evidence from the Egyptian stock market (Unpublished doctoral dissertation). University of Plymouth, Egypt.

Hanafi, M. M., Setiyono, B., \& Sanjaya, I. P. S. (2018). Ownership structure and firm performance: Evidence from the subprime crisis period. Corporate Governance: The International Journal of Business in Society, 18(2), 206-219.

Henry, D. (2010). Agency costs, ownership structure and corporate governance compliance: A private contracting perspective. Pacific-Basin Finance Journal, 18(1), 24-46.

Hoechle, D. (2007). Robust standard errors for panel regressions with cross-sectional dependence. The Stata Journal, 7(3), 281-312.

Hutchinson, M., Seamer, M., \& Chapple, L. E. (2015). Institutional investors, risk/performance and corporate governance. The International Journal of Accounting, 50(1), 31-52.

Jameson, M., Prevost, A., \& Puthenpurackal, J. (2014). Controlling shareholders, board structure, and firm performance: Evidence from India. Journal of Corporate Finance, 27, $1-20$. 
Javid, A. Y., \& Iqbal, R. (2008). Ownership concentration, corporate governance and firm performance: Evidence from Pakistan. The Pakistan Development Review, 47(4-II), pp-643.

Javid, A. Y., \& Iqbal, R. (2010). Corporate governance in Pakistan: Corporate valuation, ownership and financing. Working Papers \& Research Reports, 2010.

Jiang, B.-B., Laurenceson, J., \& Tang, K. K. (2008). Share reform and the performance of China's listed companies. China Economic Review, 19(3), 489-501.

Kao, M.-F., Hodgkinson, L., \& Jaafar, A. (2019). Ownership structure, board of directors and firm performance: Evidence from Taiwan. Corporate Governance: The International Journal of Business in Society, 19(1), 189-216.

Kirchmaier, T., \& Grant, J. (2005). Corporate ownership structure and performance in Europe. European Management Review, 2(3), 231-245.

Kumar, P., \& Zattoni, A. (2014a). Large shareholders and corporate governance outside the United States and United Kingdom. Corporate Governance: An International Review, 22(4), 294-295.

Kumar, P., \& Zattoni, A. (2014b). Ownership, managerial entrenchment, and corporate performance. Corporate Governance: An International Review, 22(1), 1-3.

Kumar, P., \& Zattoni, A. (2018). Ownership structure, corporate governance and institutional environment: Going beyond managerial opportunism and the principal-agent framework. Corporate Governance: An International Review, 26(2), 82-83.

Leung, N. W., \& Cheng, M.-A. (2013). Corporate governance and firm value: Evidence from Chinese state-controlled listed firms. China Journal of Accounting Research, $6(2), 89-112$.

Liao, J., \& Young, M. (2012). The impact of residual government ownership in privatized firms: New evidence from China. Emerging Markets Review, 13(3), 338-351.

Makki, M., Abdul, M., \& Lodhi, S. A. (2013). Impact of corporate governance on financial performance. Pakistan Journal of Social Sciences (PJSS), 33(2), 265-280.

Malan, I., Salamudin, N., \& Ahmad, N. (2014). Empirical research on characterization of pyramid structure and firm performance. Middle-East Journal of Scientific Research, 21(11), 2156-2168.

Marie L'Huillier, B. (2014). What does "corporate governance" actually mean? Corporate Governance, $14(3), 300-319$.

Minichilli, A., Brogi, M., \& Calabrò, A. (2016). Weathering the storm: Family ownership, governance, and performance through the financial and economic crisis. Corporate Governance: An International Review, 24(6), 552-568.

Mishra, R., \& Kapil, S. (2017). Effect of ownership structure and board structure on firm value: Evidence from India. Corporate Governance: The International Journal of Business in Society, 17(4), 700-726.

Mukhopadhyay, J., \& Chakraborty, I. (2017). Foreign institutional investment, business groups and firm performance: Evidence from india. Research in International Business and Finance, 39, 454-465.

O'Connor, T., \& Byrne, J. (2015). When does corporate governance matter? Evidence from across the corporate life-cycle. Managerial Finance, 41(7), 673-691.

of Grosman, A., Wright, M., \& Okhmatovskiy, I. (2016). State control and corporate 
governance in transition economies: 25 years on from 1989. Corporate Governance: An International Review, $24(3), 200-221$.

Ongore, V. O. (2011). The relationship between ownership structure and firm performance: An empirical analysis of listed companies in Kenya. African Journal of Business Management, 5(6), 2120-2128.

Pillai, R., \& Al-Malkawi, H.-A. N. (2018). On the relationship between corporate governance and firm performance: Evidence from GCC countries. Research in International Business and Finance, 44, 394-410.

Rafiq, S., Salim, R., \& Smyth, R. (2016). The moderating role of firm age in the relationship between R\&D expenditure and financial performance: Evidence from Chinese and US mining firms. Economic Modelling, 56, 122-132.

Rashid, A. (2018). Board independence and firm performance: Evidence from Bangladesh. Future Business Journal, 4(1), 34-49.

Saini, N., \& Singhania, M. (2018). Corporate governance, globalization and firm performance in emerging economies: Evidence from India. International Journal of Productivity and Performance Management, 67(8), 1310-1333.

Shahwan, T. M. (2015). The effects of corporate governance on financial performance and financial distress: Evidence from Egypt. Corporate Governance: The International Journal of Business in Society, 15(5), 641-662.

Shyu, J. (2013). Ownership structure, capital structure, and performance of group affiliation: Evidence from Taiwanese group-affiliated firms. Managerial Finance, 39(4), 404-420.

Tahir, S. H., Sohail, S., Qayyam, I., \& Mumtaz, K. (2016). Effect of corporate governance index on dividend policy: An investigation of textile industry of Pakistan. Journal of Economic and Social Development, 3(1), 139-146.

Torres, J. P., Bertín, M. J., \& López-Iturriaga, F. J. (2017). Corporate control and firm value: The bright side of business groups. Journal of Family Business Strategy, 8(2), 99-108.

Wang, B. (2018). Ownership, institutions and firm value: Cross-provincial evidence from China. Research in International Business and Finance, 44, 547-565.

Yoo, T., \& Jung, D. K. (2015). Corporate governance change and performance: The roles of traditional mechanisms in France and South Korea. Scandinavian Journal of Management, 31(1), 40-53.

Yudaeva, K., Kozlov, K., Melentieva, N., \& Ponomareva, N. (2003). Does foreign ownership matter? The Russian experience. Economics of Transition, 11(3), 383-409.

Yu-Thompson, Y., Lu-Andrews, R., \& Fu, L. (2016). Liquidity and corporate governance: Evidence from family firms. Review of Accounting and Finance, 15(2), 144-173. 